\title{
Strates
}

STRATES Matériaux pour la recherche en sciences sociales

$1 \mid 1986$

Mélanges

\section{Division sociale des espaces périurbains}

\section{Martine Berger}

\section{(2) OpenEdition}

Journals

Édition électronique

URL : http://journals.openedition.org/strates/349

DOI : $10.4000 /$ strates.349

ISSN : 1777-5442

Éditeur

Laboratoire Ladyss

Édition imprimée

Date de publication : 1 janvier 1986

ISSN : 0768-8067

Référence électronique

Martine Berger, «Division sociale des espaces périurbains », Strates [En ligne], 1 | 1986, mis en ligne le 08 décembre 2004, consulté le 08 septembre 2020. URL : http://journals.openedition.org/strates/349 ; DOI : https://doi.org/10.4000/strates.349

Ce document a été généré automatiquement le 8 septembre 2020

Tous droits réservés 


\section{Division sociale des espaces périurbains}

Martine Berger 